\title{
Estimation of Top Nitrogen Content in Rice Canopy Using Optical and Nondestructive Methods
}

\author{
Kiyoshi Iwaya*, Haruhiko Yamamoto**, \\ Seiji HayaKawA** and Makio KamichiKA*** \\ $\left(\begin{array}{c}* \text { The Graduate School of Agricultural Sciences, Tottori University, Tottori, 680-8553 Japan } \\ * * \text { Faculty of Agriculture, Yamaguchi University, Yamaguchi, 753-8515 Japan } \\ * * * \text { Arid Land Research Center, Tottori University, Tottori, 680-0001 Japan }\end{array}\right)$
}

\begin{abstract}
The top nitrogen content (TNC) per unit area $\left(\mathrm{g} \mathrm{m}^{-2}\right)$ is an important quantitative index of the condition of nitrogen nutrition in rice production. In this study, the rapid and simple method of estimation of $T N C$, with the use of the existing nondestructive analyzing instruments chlorophyll meter SPAD-502 and plant canopy analyzer (PCA) LAI-2000, was scrutinized. The analysis in the rice cultivar Nipponbare, conducted in 1997 and 1998, showed a high positive correlation $\left(R^{2}=\right.$ 0.743, $P<0.01$ ) between the SPAD reading obtained by the chlorophyll meter and the specific leaf nitrogen $(S L N)$. The leaf area index $(L A I)$ estimated by PCA tended to underestimate the $L A I$ determined by actual measurement by about $20 \%$. Still, the estimation of $L A I$ by PCA was judged to have a sufficient accuracy as a practical technique. A high positive correlation $\left(R^{2}=0.866, P<\right.$ $0.01)$ was obtained between the product of the SPAD reading and $L A I$, and the leaf nitrogen content $(L N C)$ per unit area $\left(\mathrm{g} \mathrm{m}^{-2}\right) . L N C$ and $T N C$ also showed a very high correlation $\left(R^{2}=0.988, P<\right.$ $0.01)$. The product of the SPAD reading and $L A I$, and $T N C$ also gave a high positive correlation $\left(R^{2}\right.$ $=0.847, P<0.01)$. These results indicated that the method described in this study was effective as a simple and rapid method for the estimation of $T N C$ per unit area.
\end{abstract}

Key words: Chlorophyll meter, Leaf area index, Plant canopy analyzer, SPAD reading, Top nitrogen content.

\section{Introduction}

In the production of rice, the control of fertilizer application greatly affects not only the yield but also the product quality such as taste. Therefore, an adequate control of fertilizer application is necessary for stable rice production, and simple and accurate techniques for the diagnosis of nutritional condition of rice are important.

The chlorophyll meter (SPAD-502, Minolta Co., Ltd.) has been widely used as an instrument to diagnose the nutritional condition of rice. The value indicated by the chlorophyll meter (the SPAD reading) is primarily an indicator of the chlorophyll concentration in leaf blades. As the correlation between the chlorophyll concentration in leaf blades and the leaf nitrogen concentration is high, the diag-

Received on October 20, 2003.

Accepted on December 5, 2003. nosis of the condition of nitrogen nutrition and the control of fertilizer application by the SPAD reading have been practiced (Chubachi et al., 1986; Turner and Jund, 1991; Sakata and Yamagishi, 1995). While the leaf blade nitrogen concentration is an important qualitative index of the condition of nitrogen nutrition in rice, the top nitrogen content (TNC) per unit area $\left(\mathrm{g} \mathrm{m}^{-2}\right)$ is an important quantitative index of the condition of nitrogen nutrition. More specifically, $T N C$ per unit area in the spikelet differentiation stage has been suggested to be related to the number of rice grains per unit area, an element of the yield components. Therefore the $T N C$ per unit area is an effective index in the control for obtaining the optimal grain number and the succeeding control of fertilizer application (Saito et al., 1992; Sakata et al., 1996). For the estimation of the TNC, in addition to the qualitative analysis of the nutritional condition by the SPAD reading, the evaluation of parameters 
of biomass such as top dry weight and leaf area index is needed.

As a method of the estimation of $T N C$ of rice, a technique of the evaluation of $T N C$ per individual rice plant ( g plant $^{-1}$ ), from the SPAD reading, areas of individual leaves and the number of shoots, has been reported (Ladha et al., 1998). The TNC per individual rice plant $\left(\mathrm{g} \mathrm{plant}^{-1}\right)$ is a useful index for evaluating the efficiency of nitrogen use of individual plants in the field of plant breeding. However, in the control of plant cultivation, the TNC per unit area $\left(\mathrm{g} \mathrm{m}^{-2}\right)$ is thought to be more important. While a technique of estimation of $T N C$ per unit area from the graphic information obtained by CCD cameras has been proposed (Suguri et al., 2001; Shibata et $a l ., 2002)$, the necessity of a high degree of skill in image analysis may be an obstacle. Therefore, it is concluded that the development of a method of estimation of top nitrogen content by the use of existing analytical instruments is necessary.

The plant canopy analyzer (LAI-2000, LI-COR, Inc.) is an instrument for the estimation of leaf area index by measuring the distribution of incident and transmitted light beams in the plant canopy by a special fisheye lens (Wells and Norman, 1991). The application of the plant canopy analyzer technique to the rice canopy has shown that the accurate estimation of leaf area index is possible during the long period from just after transplanting to the boot stage (Yamamoto et al., 1995; Iwaya et al., 1998). In addition, the SPAD reading had a high correlation to the specific leaf nitrogen (SLN) (Peng et al., 1995). Based on these observations, we showed that the $T N C$ per unit area can be estimated quite precisely in rice from the product of the SPAD reading on the chlorophyll meter and the leaf area index obtained by the plant canopy analyzer, in our field test in 1997 (Iwaya et al., 1998). The present study further analyzes the method of nondestructive and rapid estimation of top nitrogen content in rice based on the results obtained in two years of field tests, combining the data obtained in 1997 and 1998.

\section{Materials and Methods}

The experiments were carried out in the rice paddies in the Agricultural Farms of the Faculty of Agriculture, Yamaguchi University in 1997 and 1998. The cultivar of rice (Oryza sativa L.) used for the experiments was Nipponbare. In each year, three types of rice canopy, with different conditions of growth and nitrogen nutrition due to three different patterns of fertilizer application, were prepared, as indicated in Table 1. They were the control group, which had the conventional fertilizer application, the non-topdressing group, which had the basal dressing but no topdressing, and the non-fertilizer group, which had no fertilizer application. The areas of test plots for these groups were $2,500 \mathrm{~m}^{2}$ for the control group, $2,540 \mathrm{~m}^{2}$ for the non-topdressing group and $970 \mathrm{~m}^{2}$ for the non-fertilizer group. The plot used for the non-fertilizer group had been used for culture with no fertilizer since 1995 . Therefore, the effect of remaining fertilizer was unlikely. In 1997, rice was seeded on May 13 and the young plants were transplanted on June 10 using a transplanting machine with the row distance of $30 \mathrm{~cm}$ and the hill distance of $16 \mathrm{~cm}$ (the planting density, 20.8 stocks per $\mathrm{m}^{2}$ ). The heading date was August 20 (71 days after the transplantation). In 1998, the seeding was on May 5. The young plants were transplanted on June 1. The heading date was August 18 (78 days after the transplantation).

The measurements were carried out following the procedures described below using 6 stocks ( 3 hills each on 2 rows) located near the center of each test plot in both years.

The measurements of leaf area index ( $L A I)$ by the plant canopy analyzer (PCA) was similar to those in Yamamoto et al. (1995) as follows. The $90^{\circ}$ view cap was used for the PCA in order to mainly measure the object stocks. First, the intensity of the incident light to the rice canopy was measured on top of the canopy. Next, it is necessary that the measurement of transmitted light in the canopy averages the measured value of several times, since light distribution in the canopy is not uniform. Then, the intensities of transmitted light were measured at 4 points located between hills, ranging from the stock base to the canopy central, as shown in Fig. 1, and the mean value was designated the measured value. The measurements were performed in triplicate on a single canopy in each test plot. The average of the three $L A I$ values was taken as the $L A I$ value for the corresponding test plot. In the determination of $L A I$ by PCA, the condition of clear sky tended to give a smaller value of estimated $L A I$, due to the effect of direct light beams from the sun (Yamamoto et al., 1995). In both years, as the measuring dates in- 
Table 1. Fertilizer application time and content in 1997 and 1998.

\begin{tabular}{|c|c|c|c|c|c|}
\hline \multirow[b]{2}{*}{$\begin{array}{l}\text { Experimental } \\
\text { year }\end{array}$} & \multirow{2}{*}{\multicolumn{2}{|c|}{ Fertilizer application time }} & \multicolumn{3}{|c|}{ Experimental plot and fertilizer content } \\
\hline & & & $\begin{array}{c}\text { Control } \\
\left(\mathrm{N}: \mathrm{P}_{2} \mathrm{O}_{5}: \mathrm{K}_{2} \mathrm{Og} \mathrm{m}^{-2}\right)\end{array}$ & $\begin{array}{c}\text { Non-topdressing } \\
\left(\mathrm{N}: \mathrm{P}_{2} \mathrm{O}_{5}: \mathrm{K}_{2} \mathrm{Og} \mathrm{m}{ }^{-2}\right)\end{array}$ & Non-fertilizer \\
\hline \multirow[t]{2}{*}{1997} & Basal dressing & May 26 & $2.4: 10.6: 3.0$ & $2.4: 10.6: 3.0$ & $\mathrm{Nf}$ \\
\hline & Topdressing & $\begin{array}{l}\text { June } 26 \\
\text { Aug. } 4 \\
\text { Aug. } 11\end{array}$ & $\begin{array}{l}1.2: 1.2: 1.0 \\
3.6: 1.2: 3.6 \\
2.4: 0.8: 2.4\end{array}$ & $\mathrm{Nf}$ & $\mathrm{Nf}$ \\
\hline \multirow[t]{2}{*}{1998} & Basal dressing & May 27 & $2.4: 10.6: 3.0$ & $2.4: 10.6: 3.0$ & $\mathrm{Nf}$ \\
\hline & Topdressing & $\begin{array}{l}\text { June } 10 \\
\text { July } 23 \\
\text { Aug. } 11\end{array}$ & $\begin{array}{l}0.8: 1.2: 1.0 \\
3.0: 1.0: 2.5 \\
3.0: 1.0: 2.5\end{array}$ & $\mathrm{Nf}$ & $\mathrm{Nf}$ \\
\hline
\end{tabular}

Nf: non-fertilizer.

cluded both sunny and cloudy days; the measurements in the field were done after 17:00 when the effect of direct sunlight became smaller.

After the PCA measurements, the rice plant of the same stock was used for the measurements by the chlorophyll meter. In each stock, the second uppermost leaf among the fully-developed leaf group on the main (or similar) shoot was used for the measurement. The number of measurement points were five on the leaf, located near the center of the leaf blade, avoiding the midrib. As it has been reported that the value of the SPAD reading was different depending on the side of the leaf-halves (Mimoto et al., 1995), the SPAD reading was taken on both sides across the midrib. The average of 30 values measured in 6 stocks was taken as the measured value for each test plot.

After the above-mentioned processes, the rice plants at the measuring site were removed from the paddy. The leaf area was measured by the automatic area meter (AAM-8, Hayashi Denko Co., Ltd.) after the different parts of the plants were separated. The separated parts of the rice plants were dried for $48 \mathrm{~h}$ in an air-ventilation drier at $90^{\circ} \mathrm{C}$. The dry weights of the dried leaf blades and stems were measured separately. Then, they were pulverized in a grinder. The nitrogen content in each fraction was determined by the Kjeldahl method.

These measurements were carried out three times in 1997, on July 24, August 4 and August 15 (44, 55 and 66 days after the transplantation, respectively). In 1998, the measurements were done four times on July 13, July 30, August 8 and August 17 (42, 59, 68 and 77 days after the transplantation, respectively).

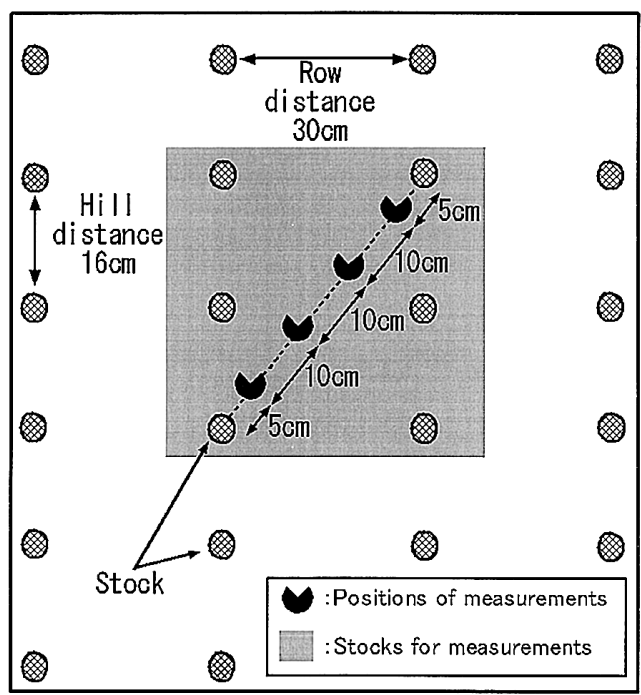

Fig. 1. Positions of measurements for plant canopy analyzer in experimental plots.

\section{Results and Discussion}

3.1 Time-courses of air temperature, sunshine duration, SPAD readings and $L A I$ in the test years

The time-courses of the pentad mean air temperature and the pentad integrated sunshine duration after the date of transplantation in 1997 and 1998 are shown in Figs. 2 and 3. The corresponding normal values are shown for comparison. Changes in the SPAD reading and the measured $L A I$ value are also shown in Figs. 2 and 3. The meteorological data were taken from the observations at the Yamaguchi Meteorological Station, located about $2 \mathrm{~km}$ from the test plots of the Agricultural Farms. The error bars in the SPAD diagrams indicate standard deviations 
of the observed values.

The air temperature in 1997 was somewhat higher than normal from transplanting time to early July. It was near normal afterwards. In 1998, the air temperature was above normal in early July and early August, but it was near normal in other periods. In 1997, the sunshine duration was quite a bit shorter than normal in mid July and early-to-mid August. In other periods, it was near normal or above normal. In 1998, the sunshine duration was much shorter than normal in early June and late June. It was also shorter in the period from late July to early August. The comparison of these two years showed a tendency of less sunshine in mid July and the earlier half of August in 1997; in contrast, sunshine duration was longer and temperature was higher than normal in these periods in 1998.

The SPAD reading of the sample in the nontopdressing plot was higher than that of the control at the start of measurement period. However, the value in the non-topdressing plot sharply dropped
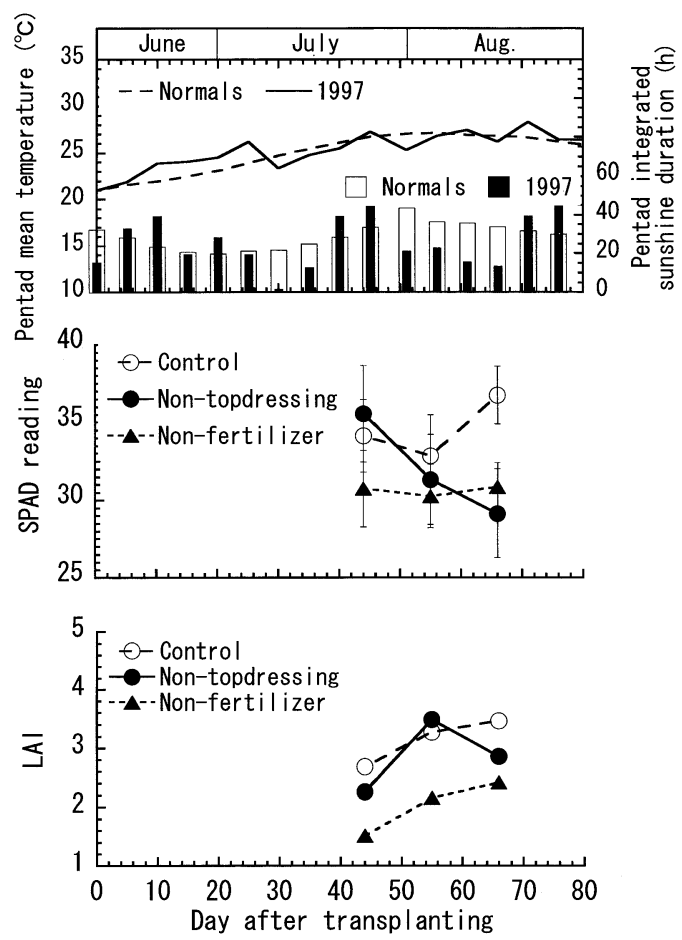

Fig. 2. Time-courses of pentad mean air temperature, pentad integrated sunshine duration, SPAD reading and measured $L A I$ in 1997 . In SPAD reading plots, an error bar shows standard deviation for each datum. and became below the value of the control. The value of the control rose after the third topdressing to 36.7. The SPAD readings in the control and non-topdressing plots in 1998 were similar to those in 1997. However, the reading in the non-fertilizer plot dropped sharply during the period of measurement. The values of the SPAD reading were in the range from 25.9 to 36.7 in the whole two-year period.

The values of $L A I$, in general, were highest in the control plot, followed by the non-topdressing plot and then the non-fertilizer plot during the period of measurements in 1997. An exception was that the value in the non-topdressing plot was higher than that in the control plot in the measurement 55 days after the transplantation. In 1998, the $L A I$ values in the three test plots were approximately the same at the start of the measurement period. Afterwards, the $L A I$ values rose gradually; the extent of the increase was in the order of the control plot, the nontopdressing plot and the non-fertilizer plot. While the highest value of LAI observed in 1997 was 3.49,
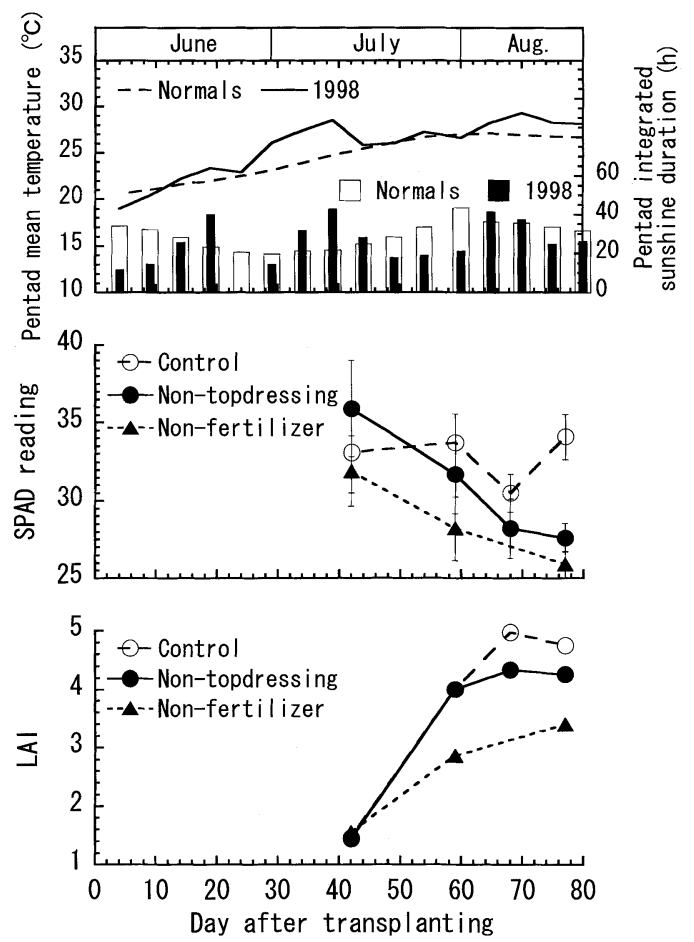

Fig. 3. Time-courses of pentad mean air temperature, pentad integrated sunshine duration, SPAD reading and measured $L A I$ in 1998 . In SPAD reading plots, an error bar shows standard deviation for each datum. 
a value less than 4, the highest value observed in 1998 was 4.97.

\subsection{Relationship between the SPAD reading of leaf blade of rice and the specific leaf nitrogen}

The relationship between the SPAD reading and the specific leaf nitrogen ( $S L N, \mathrm{~g} \mathrm{~m}^{-2}$ ) observed in 1997 and 1998 is shown in Fig. 4. They had a positive correlation, which can be expressed by the following equation,

$$
y=-0.111+0.0376 x
$$

where $y$ corresponds to $S L N\left(\mathrm{~g} \mathrm{~m}^{-2}\right)$ and $x$ corresponds to the SPAD reading. The coefficient of determination, $R^{2}$, was $0.743(P<0.01)$. The results reported by Peng et al. (1995) on rice genotypes in the International Rice Research Institute (IRRI) gave a similar correlation $(r=0.79-0.90)$. The correlation between the SPAD reading and the leaf nitrogen concentration, a parameter generally associated with the SPAD reading, had a coefficient of determination of 0.725 , a value lower than that for $S L N$. In this respect, too, our result was similar to that obtained by Peng et al. (1995). These results indicates that the SPAD reading can be used as an index for $S L N$.

\section{3 Estimation of $L A I$ by PCA in rice}

The relationship between the estimated values of $L A I$ by PCA and the values of $L A I$ actually determined by sampling is shown in Fig. 5. The coefficient of determination, $R^{2}$, was $0.892(P<0.01)$. The relationship can be expressed by the following equation,

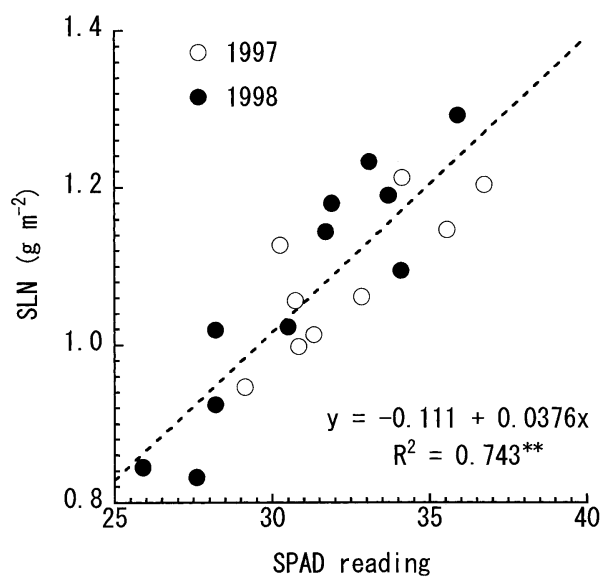

Fig. 4. Relationship between SPAD reading and SLN (specific leaf nitrogen, $\mathrm{g} \mathrm{m}^{-2}$ ). ** shows significance at $P<0.01$.

$$
y=-0.0287+1.19 x
$$

where $y$ is the actually determined value of $L A I$ and $x$ is the value of $L A I$ estimated by PCA. This result was compared to the regression in rice reported by Yamamoto et al. (1995) $(y=-0.04+1.05 x, r=0.98)$. In these two studies, the $y$-intercepts were similar but the inclinations were different. In our present study, the values of $L A I$ in rice population, estimated by using PCA, tended to be about 20\% less than the actually determined values of $L A I$. This tendency of underestimation was more marked when the actually-determined $L A I$ was more than 4 . In other reports, it is reported that the PCA underestimates $L A I$ on rice plant canopy (Yamamoto et al., 1995) and corn canopy (Wilhelm et al., 2000) in which $L A I$ becomes over 4. PCA estimates $L A I$ by calculating the gap fraction from the measurement of transmitted light in a plant canopy. Therefore, when the value of $L A I$ is high, due to exuberant growth of foliage, overlapping of leaves intercepting the transmitted light beam is no longer negligible. This situation probably induces the underestimation of the overlapping of leaf blades.

However, no practical method of nondestructive and noncontact estimation of $L A I$ in rice has been established except PCA. Therefore, at present, PCA is considered to be a rapid and effective method of the estimation of $L A I$.

\section{4 Estimation of top nitrogen content per unit area by using chlorophyll meter and PCA}

The leaf nitrogen content $(L N C)$ per unit area

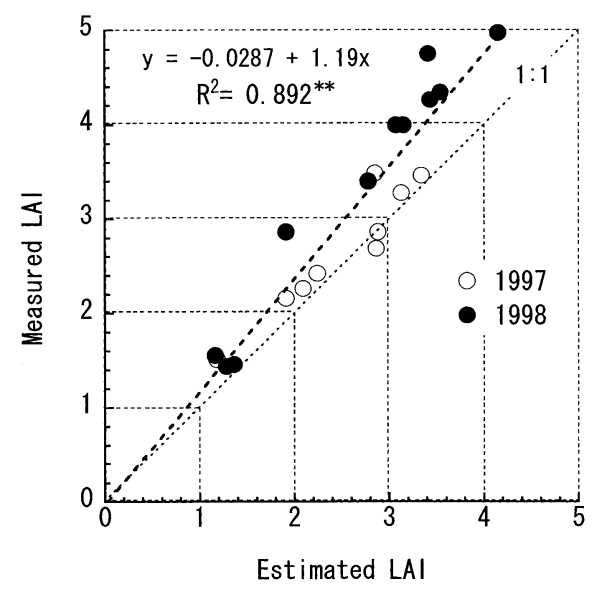

Fig. 5. Relationship between estimated $L A I$ by PCA and measured LAI. ** shows significance at $P<0.01$. 
$\left(\mathrm{g} \mathrm{m}^{-2}\right)$ can be obtained as the product of the amount of nitrogen per unit leaf area (specific leaf nitrogen, $S L N$ ) and the total leaf area per unit area (leaf area index, $L A I$ ). From the analysis in 3.2, it was shown that the SPAD reading could be used as the index of $S L N$. Similarly, in 3.3, the estimation of $L A I$ by PCA was shown to be adequate. Therefore, it is concluded that $L N C$ per unit area can be estimated from the product of the SPAD reading and $L A I$ obtained by PCA. The relationship between the product of the SPAD reading and $L A I$ obtained by PCA, and the value of $L N C$ per unit area is presented in Fig. 6. The relationship obtained in the two years of 1997 and 1998 can be expressed by the following equation, with a high positive correlation $\left(R^{2}=0.866, P<0.01\right)$,

$$
y=0.195+0.0383 x
$$

where, $y$ is $L N C\left(\mathrm{~g} \mathrm{~m}^{-2}\right), x$ represents the product of the SPAD reading and $L A I$ obtained by PCA.

As the quantitative index for the condition of nitrogen nutrition of rice, the top nitrogen content (TNC) per unit area $\left(\mathrm{g} \mathrm{m}^{-2}\right)$ is more important than $L N C$. In particular, it has been shown that $T N C$ per unit area in the spikelet differentiation stage has a high positive correlation to the number of grains per unit area, an element of the yield components (Saito et al., 1992; Sakata et al., 1996). Therefore, TNC is probably an important index for obtaining the optimal number of grains and in the control of fertilizer application for the estimated total number of grains. If a high correlation is obtained between $L N C$ and

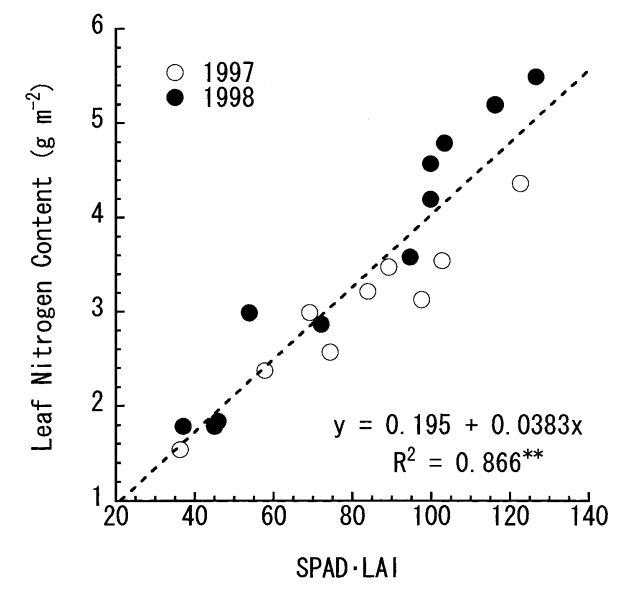

Fig. 6. Relationship between product of SPAD reading and $L A I$ and leaf nitrogen content $\left(L N C, \mathrm{~g} \mathrm{~m}^{-2}\right) . \quad * *$ shows significance at $P<0.01$.
$T N C$, it should be possible to estimate the value of $T N C$ from the product of the SPAD reading and the value of $L A I$ obtained by PCA, based on the result shown in Fig. 6. The relationship between $L N C$ per unit area and TNC per unit area is shown in Fig. 7. In the two years of 1997 and 1998, LNC and TNC had a very high positive correlation $\left(R^{2}=0.988, P<\right.$ $0.01)$.

The relationship between the product of the SPAD reading and $L A I$ obtained by $P C A$ and the value of TNC per unit area is presented in Fig. 8. The relationship between these two parameters can be expressed by the following equation. They had a

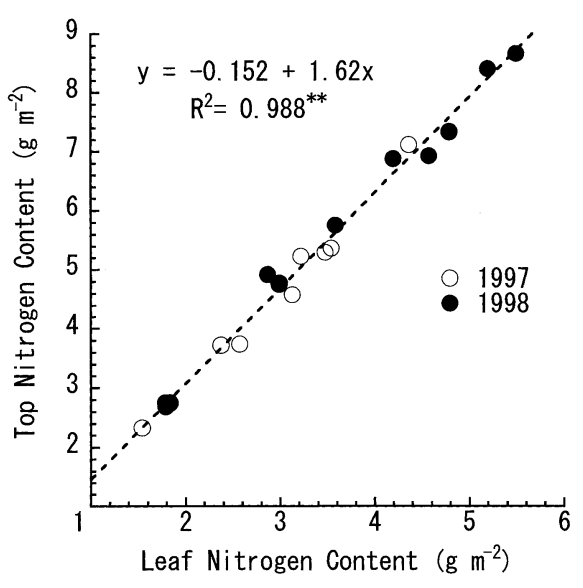

Fig. 7. Relationship between leaf nitrogen content $\left(L N C, \mathrm{~g} \mathrm{~m}^{-2}\right)$ and top nitrogen content (TNC, $\left.\mathrm{g} \mathrm{m}^{-2}\right) . \quad * *$ shows significance at $P<0.01$.

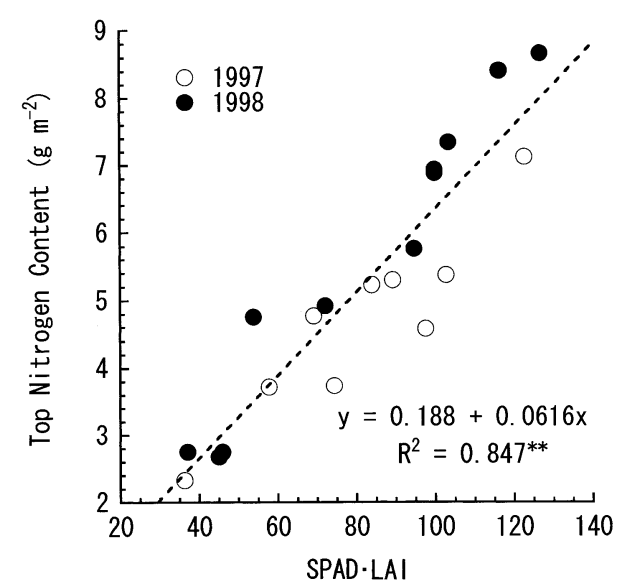

Fig. 8. Relationship between product of SPAD reading and $L A I$ and top nitrogen content $\left(T N C, \mathrm{~g} \mathrm{~m}^{-2}\right) . \quad * *$ shows significance at $P<0.01$. 
high positive correlation $\left(R^{2}=0.847, \quad P<0.01\right)$, though the coefficient of determination was slightly smaller in the case of Fig. 8 than in Fig. 6.

$$
y=0.188+0.0616 x
$$

where $y$ is $T N C\left(\mathrm{~g} \mathrm{~m}^{-2}\right)$ and $x$ is the product of the SPAD reading and $L A I$ obtained by PCA.

From these results, it was suggested that $T N C$ per unit area can be estimated accurately and rapidly from the product of the SPAD reading taken by the chlorophyll meter and the value of $L A I$ determined by PCA in a cultivar of rice up to the stage of heading. Both of the chlorophyll meter and PCA are current, commercially-available analytical instruments. It may be necessary to assess the possibility of application of this technique in other rice cultivars and crops.

\section{Conclusion}

In this study, we analyzed the method of rapid estimation of TNC $\left(\mathrm{g} \mathrm{m}^{-2}\right)$, a quantitative index of the condition of nitrogen nutrition in rice population, using nondestructive measuring instruments, a chlorophyll meter and PCA. The conclusions are as follows.

1) The values of the SPAD reading and $S L N$ observed in 1997 and 1998 had a positive correlation $\left(R^{2}=0.743\right)$.

2) The value of $L A I$ estimated by PCA tended to underestimate the actually-determined value of $L A I$ by about $20 \%$. This tendency of underestimation was marked when the actuallydetermined value of $L A I$ was more than 4. Still, the noncontact and nondestructive method of estimation of $L A I$ by PCA in rice canopy can be regarded as a practically applicable technique.

3) A high positive correlation $\left(R^{2}=0.866\right)$ was obtained between the product of the SPAD reading and the value of $L A I$ measured by PCA, and $L N C\left(\mathrm{~g} \mathrm{~m}^{-2}\right)$ through two years of experiments. $L N C$ and $T N C$ also showed a high correlation without yearly deviation. Based on these results, the relationship between the product of the SPAD reading and the value of $L A I$, and $T N C$ was further analyzed. They had a high correlation $\left(R^{2}\right.$ $=0.847)$ through two years of study. The possibility of the high-precise and quick estimation by this technique was indicated.

\section{References}

Chubachi, T., Asano, I. and Oikawa, T., 1986: The diagnosis of nitrogen nutrition of rice plants (Sasanishiki) using chlorophyll-meter. Jpn. J. Soil Sci. Plant Nutr., 57, 190-193.

Iwaya, K., Yamamoto, H. and Hayakawa, S., 1998: Estimation of nitrogen content of rice by using chlorophyll meter and plant canopy analyzer. Jpn. J. Crop Sci., 67 (Extra issue 1), 188-189.

Ladha, J.K., Tirol-Padre, A., Punzalan, G.C., Castillo, E., Singh, U. and Reddy, C. K., 1998: Nondestructive estimation of shoot nitrogen in different rice genotypes. Agron. J., 90, 33-40.

Mimoto, H., Imai, K., Daimon, H. and Ohe, M., 1995: Regularity in variation of leaf color and nitrogen distribution in half-leaf blade by leaf position on stems of rice plants. I. Variation of chlorophyll meter values and mechanism of leaf formation. Jpn. J. Crop Sci., 64, 726-733.

Peng, S., Laza, R. C., Garcia, F. V. and Cassman, K. G., 1995: Chlorophyll meter estimates leaf area based nitrogen concentration of rice. Commun. Soil Sci. Plant Anal., 26, 927-935.

Saito, K., Miyama, M., Yamamoto, J. and Katsukita, H., 1992: Diagnosis of nitrogen nutrition of rice cv. Koshihikari using chlorophyllmeter. Bull. Chiba Agric. Exp. Stn., 33, 27-35.

Sakata, M. and Yamagishi, A., 1995: Diagnosis of nitrogen nutrition for early season cultivar rice. I. Relationship between chlorophyllmeter and nitrogen concentration of leaf blade. Bull. Kochi Agric. Res. Cent., 4, 43-48.

Sakata, M., Iwasaki, A. and Yamagishi, A., 1996: Diagnosis of nitrogen nutrition for early season cultivar rice. II. Preferable growth and leaf color of rice cultivar 'Koshihikari' at latter spikelet differentiation stage. Bull. Kochi Agric. Res. Cent., 5, 82-89.

Shibata, Y., Sasaki, R., Toriyama, K. and Araki, K., 2002: Development of image mapping techniques for site-specific paddy rice management. J. Jpn. Soc. Agric. Machinery, 64, 127-135.

Suguri, M., Iida, K., Umeda, M., Inamura, T. and Matsui, T., 2001: Estimation of nitrogen content using machine vision in paddy field. J. Jpn. Soc. Agric. Machinery, 63, 59-66.

Turner, F.T. and Jund, M.F., 1991: Chlorophyll meter to predict nitrogen topdress requirement for semidwarf rice. Agron. J., 83, 926-928.

Wells, J. and Norman, J. M., 1991: Instrument for indirect measurement of canopy architecture. Agron. J., 83, 818-825.

Wilhelm, W. W., Ruwe, K. and Schlemmer, M. R., 2000: Comparison of three leaf area index meters in a corn canopy. Crop Sci., 40, 1179-1183. 
Yamamoto, H., Suzuki, Y. and Hayakawa, S., 1995: Estimation of leaf area index in crop canopies using plant canopy analyzer. Jpn. J. Crop Sci., 64, 333-335.

\title{
光学的非破壊手法による水稲個体群の地上部窒素量の推定
}

\author{
岩谷 潔* ・ 山本晴彦**・早川誠而**・神近牧男*** \\ $\left(\begin{array}{c}* \text { 鳥取大学大学院連合農学研究科 } \\ * * \text { 山口大学農学部 } \\ * * * \text { 鳥取大学乾燥地研究センター }\end{array}\right)$
}

要

水稲生産において単位面積あたりの地上部窒素量 $\left(T N C, \mathrm{~g} \mathrm{~m}^{-2}\right)$ は重要な窒素栄養状態の量的指標であ る。本研究では, 既存の非破壊測定機器である葉緑素計 SPAD-502 およびプラントキャノピーアナライザー （PCA）LAI-2000を用いて，単位面積あたり TNCの 簡易かつ迅速な推定手法について検討を行った。供試品 種に日本晴を用いて 1997 年㧍よび 1998 年に行った試 験より, 葉緑素計による SPAD 值は葉面積あたりの窒 素量 $(S L N)$ と高い正の相関 $\left(R^{2}=0.743, P<0.01\right)$ を 示した。また, PCA による葉面積指数 $(L A I)$ は実測に よる $L A I$ を $20 \%$ 過少評価する傾向があったが, 実用技
約

術としては十分な精度と考えられた。SPAD 值と $L A I$ の積と単位面積あたりの葉身窒素量 $(L N C)$ の間に高い 正の相関 $\left(R^{2}=0.866, P<0.01\right)$ が得られ, $L N C$ と $T N C$ の間にも極めて高い相関 $\left(R^{2}=0.988, P<0.01\right)$ が得られた。この結果, SPAD 值と $L A I$ の積と, 単位 面積あたり $T N C$ の間にあ高い正の相関 $\left(R^{2}=0.847, P\right.$ <0.01）が得られたことから, 本研究による手法が単位 面積あたり TNC の簡易汃迅速な推定手法として有効 であることが示唆された。

キーワード: SPAD 值, 地上部窒素量, プラントキャノ ピーアナライザー, 葉面積指数, 葉緑素計 